пролапс геніталій легкого чи середнього ступеню у 32\% (27), в той час як в контрольній групі даної патології не виявлено.

Висновки. Виявлені патологічні стани у жінок репродуктивного віку можуть бути свідченням порушення синергічної взаємодії андрогенів 3 естрадіолом, яка вкрай необхідна для забезпечення повноцінних фізіологічних ефектів в цілісному організмі жінки, тому будь-які порушення синтезу та метаболізму андрогенів можуть мати негативні наслідки для багатьох складових жіночого здоров'я і для якості життя в цілому. Тому в спілкуванні 3 пацієнтами слід звертати увагу і на такі скарги, як сексуальні порушення, зміни настрою, погане самопочуття та фізична слабкість, порушення пам'яті, розлади сечовипускання та ознаки атрофічних змін нижніх відділів генітального тракту жінок в репродуктивному віці.

\section{ЛІТЕРАТУРА}

1. Bosdou JK, Venetis CA, Kolibianakis EM, et al. The use of androgens or androgen-modulating agents in poor responders undergoing in vitro fertilization: a systematic review and meta-analysis. Hum Reprod Update. 2012 Mar-Apr; 18(2):127-45.

2. Nappi R. Androgens and postmenopausal sexuality. Proceedings 8th European congress of menopause. London, UK, May 16-20, 2009, p. S10.

3. Kalinchenko SYu, Tyuzikov IA, Grekov EA, Apetov SS, Vorslov LO, Tishova Y.A. [Androgens and lower urinary tract symptoms: only male gender or unsolved problems of both sexes?] Eksperimentalnaya i Klinicheskaya Urologiya. 2013; (4):40-48. [Russian].

Дата надходження до редакції 26.10.2018 p.

https://doi.org/10.24026/1818-1384.4(64).2018.150164

\title{
ЗВ'ЯЗОК ГІПЕРПРОЛАКТИНЕМІЇ З АНЕМІЄЮ У ХВОРИХ НА ХРОНІЧНУ ХВОРОБУ НИРОК БД СТАДІЇ
}

\author{
І.О. Дудар, В.М. Савчук, І.М. Шіфріс, О.М. Лобода, Ю.І. Гончар \\ ДУ «Інститут нефрологї НАМН України»
}

Кількість пацієнтів, які лікуються нирковозамісною терапією (НЗТ), у світі щорічно зростає. Незважаючи на прогрес у лікуванні хронічної хвороби нирок (XXH), багато метаболічних та ендокринних розладів, пов'язаних 3 хронічною уремією, залишаються невирішеними.

Поширеність гіперпролактинемії у хворих на XXH становить від 30\% до 65\%. За умови XXН продукція та елімінація пролактину (ПЛ) змінюються. Відмічають негативну кореляцію між швидкістю клубочкової фільтрації (ШКФ) та рівнем ПЛ, індексом маси тіла (IMT) та ПЛ, рівнем фосфору і кальцію та ПЛ, а також між низьким рівнем альбуміну і гемоглобіну та ПЛ.

Мета: Визначити зв'язок рівнів пролактину 3 частотою анемії та рівнем серцево-судинних подій у хворих на ХХН 5Д стадії.

Матеріали та методи. У проспективне когортне дослідження включено 55 хворих на XXH VД стадії 3 анемією, які отримують лікування гемодіалізом (ГД) у Київському міському науково-практичному центрі нефрології та діалізу, що $є$ клінічною базою
ДУ «Інститут нефрології НАМН України». Середній вік пацієнтів становив 51,4 $\pm 11,5$ року. 3 загального числа обстежених жінок було 35 (63,6\%) та чоловіків - 20 (36,4\%). Окрім стандартних методів дослідження всім хворим визначався рівень пролактину сироватки крові.

Результати. 24 пацієнти (44\%) мали рівні ПЛ

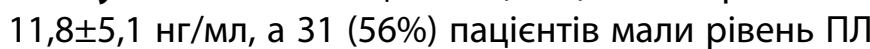

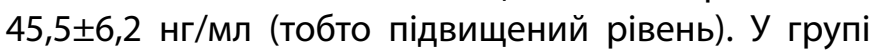
3 підвищеним рівнем ПЛ анемія реєструвалася достовірно частіше, ніж у пацієнтів 3 нормальним рівнем ПЛ (р <0,01) при дозі еритропоезстимулювальних препаратів 50 ОД/кг/тиждень.

Частота серцево-судинних подій у пацієнтів 3 підвищеним рівнем ПЛ була достовірно вищою, ніж у пацієнтів з нормальним рівнем ПЛ ( $p<0,01)$.

Висновки. Визначення рівня пролактину має важливе значення, оскільки цей гормон $\epsilon$ предиктором збільшення смертності, в тому числі, серцево-судинної, прогресування атеросклерозу, виникнення гонадальної дисфункції, гінекомастії, 
прогресування остеопорозу та персистування анеміі.

\section{ЛITEPATУРA}

1. Kolesnyk $M O$, editor. Natsionalnyi reestr khvorykh na khronichnu khvorobu nyrok ta patsientiv $z$ hostrym poshkodzhenniam nyrok: 2017 rik [National registry of patients with chronic kidney disease and patients with acute kidney damage: 2017]. Kyiv; 2018. 183 p. [In Ukrainian].

2. Melmed S, Casanueva FF, Hoffman AR, et al. Diagnosis and treatment of hyperprolactinemia: an Endocrine

Дата надходження до редакції 23.10.2018 p.
Society clinical practice guideline. J Clin Endocrinol Metab. 2011; 96(2):273-88.

3. Lakshmi D, Meera KS, Mahesh E. Serum prolactin level and inflammation in chronic kidney disease. International Journal of Biochemistry Research \& Review. 2016; 14(1):1-9.

4. Lo JC, Beck GJ, Kaysen GA, et al. Hyperprolactinemia in end stage renal disease and effects of frequent hemodialysis. Hemodial Int. 2017; 21(2):190-196.

https://doi.org/10.24026/1818-1384.4(64).2018.150165

\title{
ПРЕДИКТОРИ РОЗВИТКУ МЕТАБОЛІЧНОГО СИНДРОМУ В ПЕДІАТРИЧНІЙ ПРАКТИЦІ
}

\author{
В.М. Дудник, І.І. Андрікевич, А.В. Хромих, К.В. Хромих \\ Вінницький національний медичний університет ім. М.І. Пирогова
}

За даними ВОО3 метаболічний синдром (MC) $\epsilon$ епідемією 21 століття. Згідно останніх епідеміологічних досліджень серед дітей та підлітків частота МС становить 4-7,6 \%. Точні дані про поширеність цього небезпечного синдрому серед підлітків і дітей молодшого віку практично відсутні та обмежуються лише невеликими відомостями про високу частоту основного його прояву - ожиріння.

Метоюнашоїроботибуло визначенняпредикторів розвитку метаболічного синдрому у дітей віком від 10 до 18 років з метою попередження розвитку ускладнень у даного контингенту.

Матеріали та методи. Проведено ретроспективний аналіз історій хвороб 52 дітей, які проходили санаторно-курортне лікування у Вінницькому дитячому кардіоревматологічному санаторії протягом 2016-2017 рр. У дослідження включались діти віком від 10 до 18 років, у яких діагностовано ожиріння, зумовлене надмірним надходженням енергетичних ресурсів (шифр MKX-10 E 66.0). Ожиріння діагностувалось, коли індекс маси тіла знаходився вище 97 центильного інтервалу відповідно стандартам фізичного розвитку, нині діючим в Україні. Для вивчення предикторів розвитку МС використані критерії, запропоновані IDF Consensus 2007 року (ожиріння, підвищення артеріального тиску (АТ), гіперглікемія). Були використані антропометричні, загальноклінічні (оцінка артеріального тиску), біохімічні та статистичні методи дослідження.

Результати та обговорення: В ході дослідження виявлено, що серед обстежених переважали хлопчики (61,5\%) над дівчатками (38,5\%), що співпадає 3 даними літератури. При цьому у половини обстежених (53,8\%) діагностовано підвищення систолічного та діастолічного АТ, що $€$ одним із критеріїв МС у дітей. При цьому лише у двох обстежених дітей $(3,8 \%)$ діагностовано порушення толерантності до глюкози під час проведення орального глюкозотолерантного тесту. Саме у цієї невеликої когорти дітей виявлено наявність трьох критеріїв, які запропоновані IDF Consensus (2007) для діагностування метаболічного синдрому. Під час виписки усім обстеженим запропоновано програму реабілітації: оптимізація способу життя, підвищення фізичної активності та обов'язкове низькокалорійне збалансоване харчування згідно віку.

Висновки. Таким чином, раннє виявлення предикторів МС у дітей та застосування у них певних профілактичних заходів запобігає виникненню таких ускладнень як цукровий діабет 2 типу, ішемічна хвороба серця, гіпертонічна хвороба, а також інвалідизації в майбутньому. 